\title{
25. 体育事業との関係からみた主媂の運動行動（特に団地における主婷について）
}

東京教育大学○日下朝子，宇土正彦

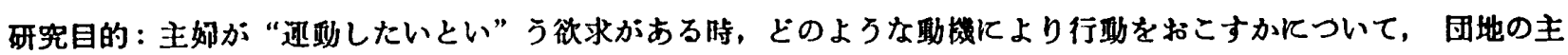

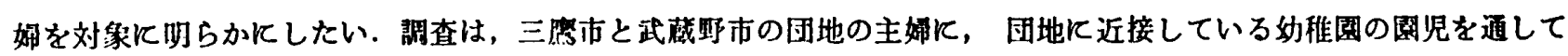
澌問紙を配り回収した。

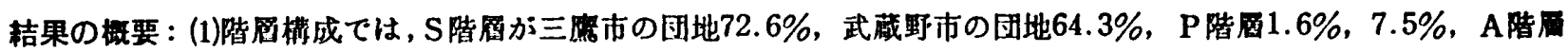

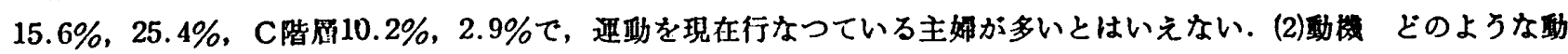

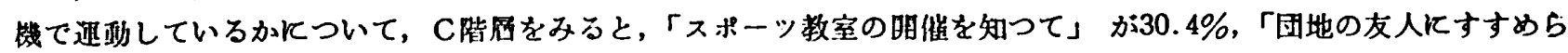

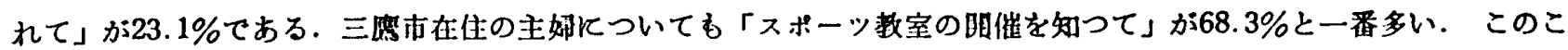
とから、「スポーツ教室」が种機としておけられる。その他の怔機についてみてみると、「子供や夫にすすめられてっが

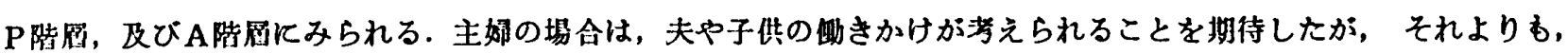

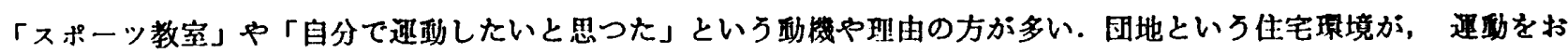

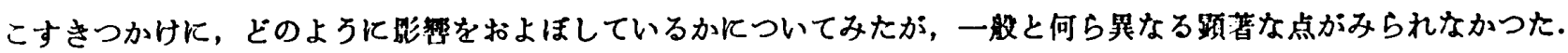
このことは，まだ団地が住居にとどまり，程営体としての栈能を有していない，その他の意味が考えられるので、こ の点につき, 更に検討を股える必要がある。

\section{6. 家庭体育に関する研究一子供の立場からみた Family Recreation一}

国学院大学○大 鋸 媔

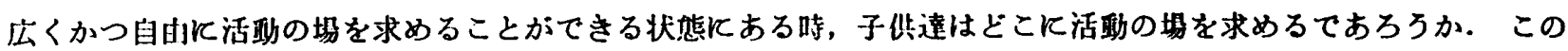

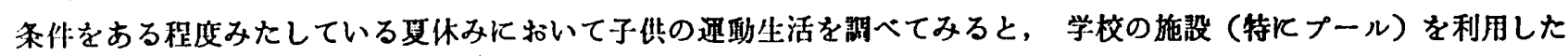

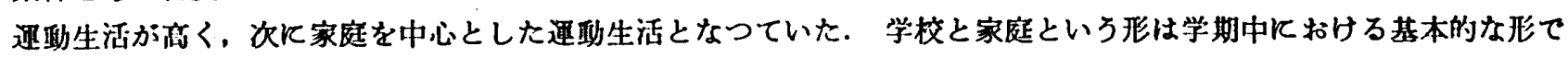

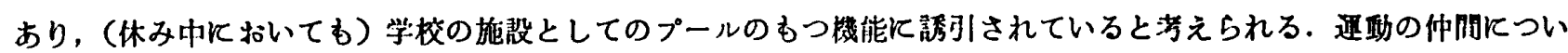

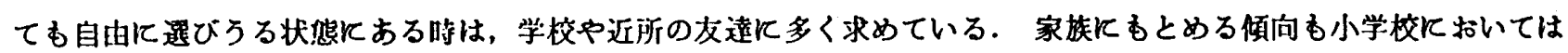
率率を示している。学校の外の施設を利用している掦合，家族との参加の形があらわれており，男女の遣いは男子は

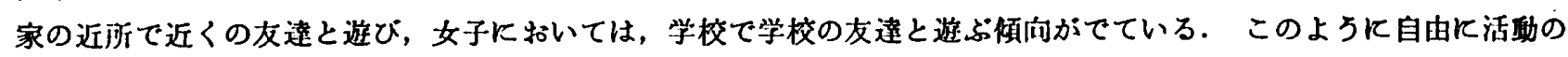

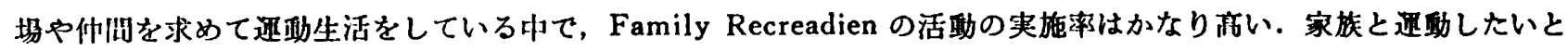

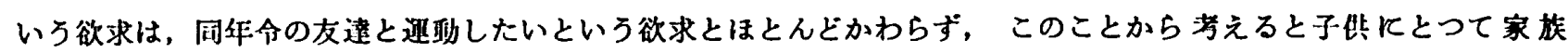
は，连動の伂間としての家族であるのか，その活㘯をしたいための助けとしての家族であるのか，そこで速動したい ための叻けとしての家族なのか，より詳糿に調查しなけれはならない。この問题についてこれからの課题としたい。

\section{7. 地域の体育事業に関する研究}

早稻田大学:教育学部 $\mathrm{O}$ 梅 沢 宣 雄

最近社会体育の振興がさけばれるようになつて，ようやく各方面に括いて，いろいろな旅策や工夫が盛んに試みら れるようになつた。

本研究は，特飞地域住民の通動生活を直接飞ささえている体有事業について，効果的な運営のあり方を考究しよろ とするものである.

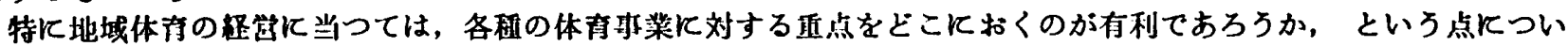

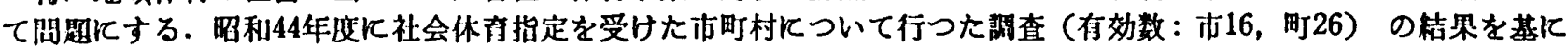

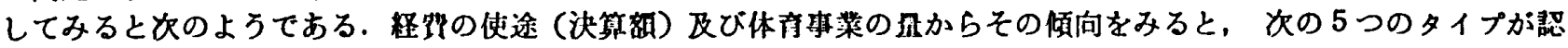
められる. I. P.S.中心型, I A.S.中心型, P.S, A.S.型, N. E.S, P.S.型, V. C.S, P.S.A.S. 型である.

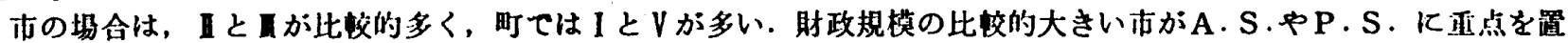
いているのに対し，町の场合は邛点主義はあまり取られていない。

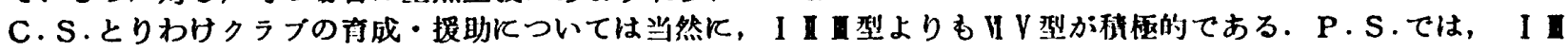
型は競技プロにかたよる㑯向がみられる。

A.S.Kついては，V型が规猎的にも，一般的施設特殊的施設のバランスからも，また一般住民への間放の点から る良い特徽を示している。

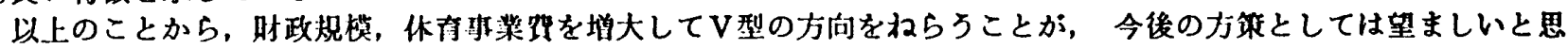
われる. 